sented at international conferences, it can only be through the agency of a national organisation. Valuable as may be the local activities of the Asiatic Society of Bengal, and of the Academies at Allahabad and Bangalore, they cannot fulfil these duties.

\section{Preparation of Woad in England}

IN a paper on "The Preparation of Woad in England", read by Messrs. H. O. Clark and R. Wailes on February 19 to the Newcomen Society, the authors said that, after being cultivated for centuries, dyer's woad (Isatis tinctoria) was last grown and prepared at Skirbeck, Lincolnshire, in 1932, and that it is not likely to be grown again either in England or elsewhere. Much has been written on the history, botany and chemistry of the plant and the dye, and the object of the paper was to place on record information as to the technology and the cost of the preparation of woad. Fortunately, on farms at Algarkirk and Skirbeck, the machinery used in the industry remains almost intact and many photographs and drawings have been made of it. At Algarkirk, too, are old account books covering the period 1844-56, and these show that the output of the farm varied from 75 tons to 178 tons and the price obtained for the prepared woad from $£ 9$ to $£ 15$. The operations involved in the preparation of woad include sowing, weeding, cropping, grinding, balling, drying, couching and packing. The most interesting of these processes was the grinding in large horse- or steam-driven mills. In the mill at Algarkirk is a circular track of oak blocks about $24 \mathrm{ft}$. in diameter on which the leaves of the plants were crushed and chopped by means of four great tapered rollers each furmished with about thirty-six cutters. The rollers were towed round the track by a large overhead castiron wheel with cast-iron spokes and a toothed rack with 456 teeth. Such mills were fine specimens of millwrighting. After the woad leaves were crushed, they were kneaded into balls by hand, and dried. A few weeks later the balls were broken up and the woad spread over the floor of the 'couching house' to a depth of about three feet. It was allowed to ferment for six to eight weeks, being turned over daily, and then was again dried, after which it was packed in barrels for dispatch to the dyers.

\section{Academic Assistance Council}

AT a meeting of the Academic Assistance Council, under the presidency of Lord Rutherford, in the rooms of the Royal Society on February 21, the Council recorded its gratitude for the generous gift from Mr. and Mrs. Simon Marks, Mr. and Mrs. Israel M. Sieff, Mr. and Mrs. Harry Sacher, Mr. and Mrs. Norman Laski and Miss Mathilda Marks of two research fellowships for displaced German men of science of the value of $£ 450$ per annum each for a period of five years. After consultation with the Royal Society, the Council awarded one fellowship for a period of three years to Dr. Walter Heitler, to enable him to continue his research in theoretical physics at the University of Bristol. Dr. Heitler, formerly of the University of Göttingen, is best known for his work in connexion with the quantum theory of valency and more recently in connexion with the theory of absorption of particles and radia. tion of high energy. The Council will shortly award the second fellowship. From its general funds the Council established a third fellowship for a period of three years, which it awarded to Dr. Veit Valentin, to enable him to continue his work in German history at University College, London. Dr. Valentin was head archivist and director of the research depart. ment for the history of culture of the German State Archives at Potsdam.

The officers of the Academic Assistance Council reported that the dismissal of university teachers in Germany on account of opinion or race is continuing, and that even after dismissal scholars are further victimised by being denied access to libraries and forbidden to accept invitations from universities and learned societies abroad. The officers also reported that six university teachers have been dismissed in Portugal for other than professional reasons. There is, therefore, continuing need for a non-political organisation to assist displaced men of science and other scholars, and the Council has made plans for the creation of a more permanent body, a Society for the Protection of Science and Learning, to take over its activities. An invitation will shortly be issued for persons to join this Society, and at the same time an appeal for funds will be made.

\section{The Universities, Social Sciences and Local Government}

REFERENCE is made in the annual report to the Court of Governors of the University of Birmingham, presented by Sir Charles Grant Robertson (vice. chancellor) on February 20, to the criticisms of Miss Fry, at the recent Annual Conference of Educational Associations : (a) that in the ratio of number of university students to population Great Britain attains only to the fifth place among the European nations; (b) that there does not exist a single university department in Great Britain dealing with causes, incidence and treatment of crime; and (c) that too large a percentage of university graduates go down almost ignorant of the structure of society and its claims upon them. As to these criticisms, the Vice-Chancellor says that "unless the community can annually and suitably absorb the output of the Universities, an increase in the number of university students will defeat the purpose for which it is made. ... What is needed even more than a knowledge of the existing social structure is the power to amend it and strengthen its capacity to absorb the trained mind ... ignorance of the structure of society is not confined to graduates; it is shared by a huge percentage of the community, including the House of Lords at one end and the recipients of Public Assistance at the other". He quotes with approval Miss Fry as reported in The Times of December 31, 1935: "In the local service there was too little bringing in of generally well educated people in the early twenties, as in the State Civil Service. The 